\title{
A Communication Based Islanding Detection Method for Photovoltaic Distributed Generation Systems
}

\author{
Gökay Bayrak and Mehmet Cebeci \\ Department of Electrical and Electronics Engineering, Faculty of Engineering, Firat University, 23100 Elazig, Turkey \\ Correspondence should be addressed to Gökay Bayrak; gokaybayrak@gmail.com
}

Received 7 March 2014; Revised 27 June 2014; Accepted 28 June 2014; Published 23 July 2014

Academic Editor: Niyaz Mohammad Mahmoodi

Copyright ( 2014 G. Bayrak and M. Cebeci. This is an open access article distributed under the Creative Commons Attribution License, which permits unrestricted use, distribution, and reproduction in any medium, provided the original work is properly cited.

PV based distributed generation (DG) systems must have some electrical connection standards while they connected to an electrical grid. One of these electrical conditions and the most important one is unplanned islanding condition. Islanding is a very dangerous condition because it could damage the PV system and related electrical systems and also working people have been at risk in islanding condition. In this application study, a new communication based islanding detection method was introduced for grid tied PV systems. A real time controller was developed with Labview for detecting islanding condition. Developed method is a hybrid method which uses the effective ways of communication based and passive methods. The results obtained from the proposed real time islanding detection method show that proposed method is reliable, robust, and independent from load and inverter. Nondetection zone (NDZ) is almost zero and islanding detection time is approximately 1-2 cycles indicated in experimental results so this time has a significant short response time according to IEEE 929-2000 standard. The proposed method is effective and presents a realistic solution to islanding so it could be implemented easily to grid tied PV systems and could be used in real system applications.

\section{Introduction}

Solar energy is one of the most promising renewable energy resources in distributed generation (DG) [1] and photovoltaic (PV) technology has been rapidly developed in the last decade [2]. Grid tied PV systems also have been coming into prominence in DG systems in parallel to this development. There have been some restrictions for PV systems such as connecting them to the utility grid just like the reliability of the grid, providing high power quality, and safety interaction with a PV system. In grid tied PV systems, particularly, the connection and balance of the PV system to the utility grid have to get some technical requirements when connected to the electrical grid. Power quality, safety interaction, and reliability of the utility are important subjects for grid tied PV power generating systems, but islanding is maybe the most important subject to this restriction for PV systems providing reliable connection and continous operation with the grid.

Abnormal operating conditions of the grid affect the PV system [3]; so PV system has to be avoided from islanding situation which is maybe the most important safety problem in a grid tied PV system. Islanding operation is defined in a DG as a situation while a grid tied PV system continues feeding the load, despite disconnection of the electrical grid from the load [4]. Islanding operation can cause damage both in the PV system and the grid so this situation has to be prevented when it occurs. In islanding situation, grid voltage and grid frequency are not stable and these values change from the grid reference values so a circuit breaker (CB) connected between the grid and the point of common coupling (PCC) must be used for opening the circuit during islanding mode. Meanwhile, DG still supplies the power to the local load if CB cannot be controlled to open the circuit [5]. Voltage shutdown, equipment failure, and short-circuit situations cause the unpredictable interruption of the grid and these abnormal situations cause islanding operation in a PV system [6].

There have been two islanding operations and one of them is the intentional islanding and the other one is defined as the unintentional islanding [7]. Intentional islanding is 


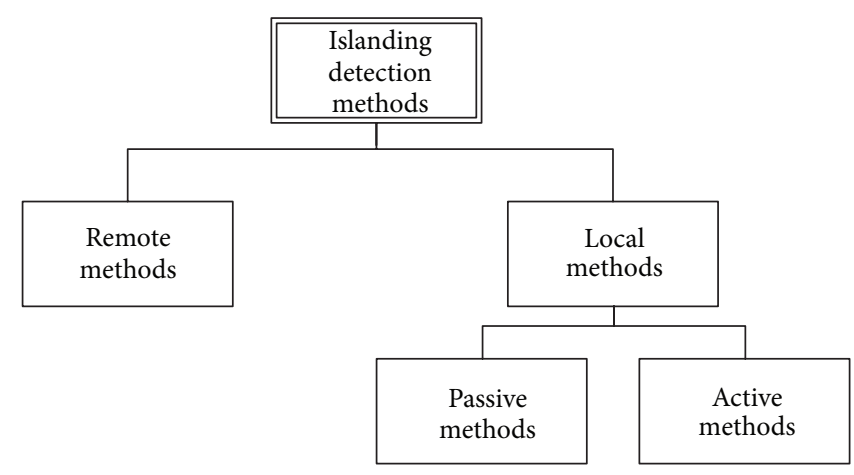

FIGURE 1: Classification of islanding detection methods.

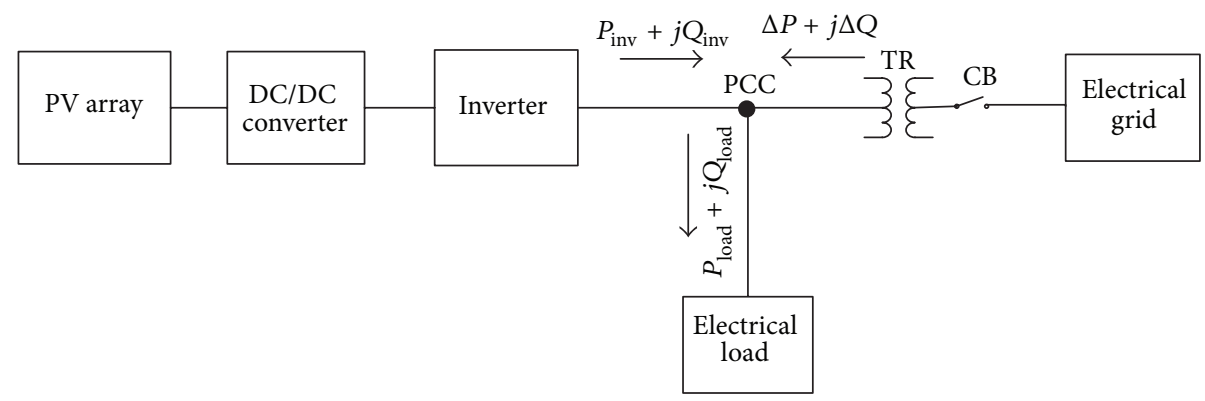

FIGURE 2: Islanding in a grid tied PV system.

used for creating a power island when a disturbance occurs and this mode sectionalizes the utility system for this aim. Also a power management plan must be operated in an intentional islanding which is created for supplying the local load constantly by DG. Intentional islanding is generally a planned operation organized by the grid authorized people so it is not harmful to the power system [8]. However, unintentional islanding can damage the grid due to losing the synchronization of electrical grid by causing the significant change of power system stability. As a result, this situation causes the voltage and frequency to be out of desired grid reference ranges and this condition can cause damage to the electrical devices and equipment of the system in islanded DG part. There is also a dangerous situation for the authorized people who work in the grid tied PV system because they cannot realize that DG continously supplies power to the islanded part of the system and this situation is a dangerous safety problem in the system. Even defining this problem in a grid tied PV system is an enough criterion for understanding the importance of the islanding so islanding should be detected as soon as possible and this situation always should be considered by the authorized DG people and companies.

Consequently, a DG consists of a PV system and should be disconnected from the local load by using a circuit breaker which is triggered by a generated control signal due to the fact that these restrictions [9]. Today, there have been many islanding detection methods and algorithms in the literature [10]. Generally, these islanding methods are classified into two main methods called local and remote detection methods. Remote methods are related to measuring system parameters at a DG, in case local methods use a communication based method between DG and the grid. The fundamental classification of islanding detection methods [11] are also shown in Figure 1.

\section{Islanding Detection Methods}

There are a lot of methods for detecting an islanding condition and these methods use different parameters to achieve islanding detection. Islanding operation is defined in a DG as a situation while a grid tied PV system continues feeding the load, despite disconnection of the electrical grid from the load [12]. Islanding condition in a grid tied PV system is indicated in Figure 2. Voltage and frequency of the system change from reference values in an islanding condition so the grid should be disconnected from the grid tied PV system without causing any damage in the system. Because of this, islanding detection methods have an important role in detecting the islanding in a grid tied PV systems.

Passive, active, and communication methods are generally researched in the literature for islanding detection in grid tied PV systems, but there have been some restrictions about these methods for using them in practical applications.

Passive methods are preferred in PV based DG systems because of their easy implementation and practical solution to the subject and these methods are thought to be the 


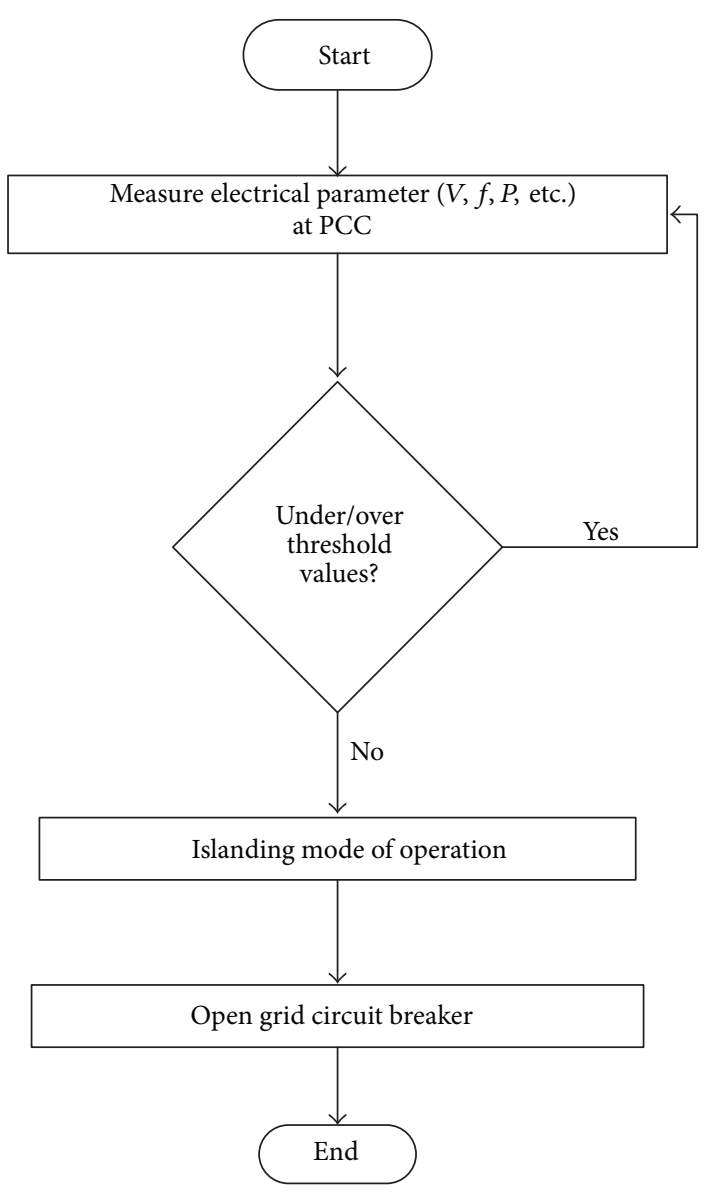

FIGURE 3: General operation of passive methods.

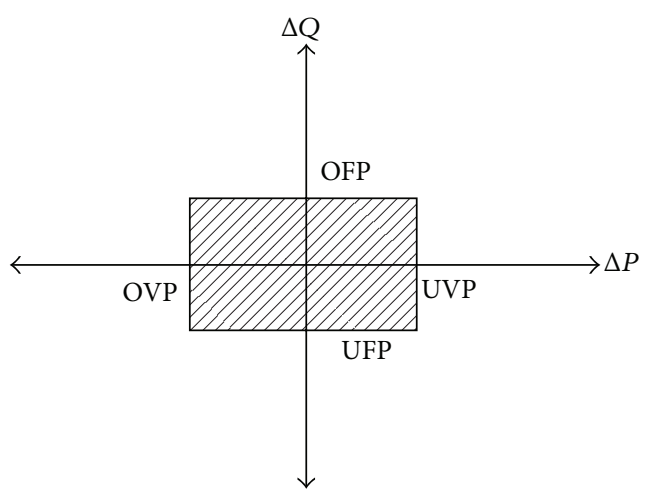

FIGURE 4: Nondetection zone (NDZ).

fundamental detection methods for detecting islanding. In addition, passive methods do not cause any change in power quality. Besides, passive methods have some drawbacks like having a large nondetection zone (NDZ) and setting threshold values with difficulty and these methods are unsuccessful for islanding detection, especially the power balance of the load and the PV system [13]. General operation of passive methods could be seen in Figure 3.

NDZ shown in Figure 4 is very small in active methods compared to passive methods and NDZ can be ignored as having high quality $(Q)$ factor loads. There is a disturbing signal which is used in active methods and also over/under voltage and frequency passive methods are used behind active methods so this condition changes the power quality of the system. Power quality changes significantly in active methods, especially connecting more inverters to the same DG [14].

Active methods use a disturbing signal for detecting islanding mode of operation. When the grid is connected, disturbance signal changes in very small limitations, but 


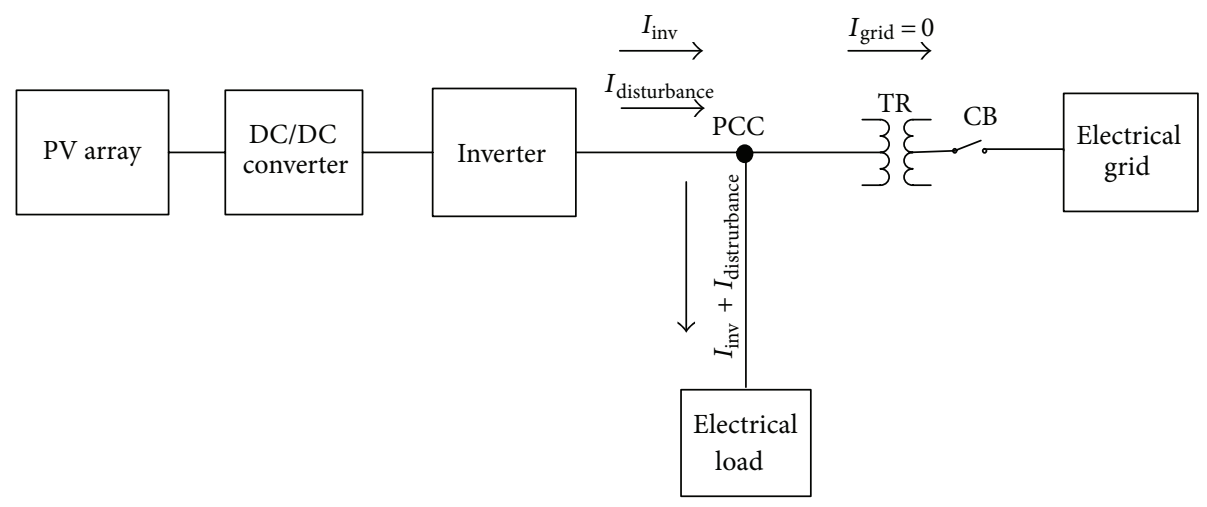

FIGURE 5: General structure of active methods.

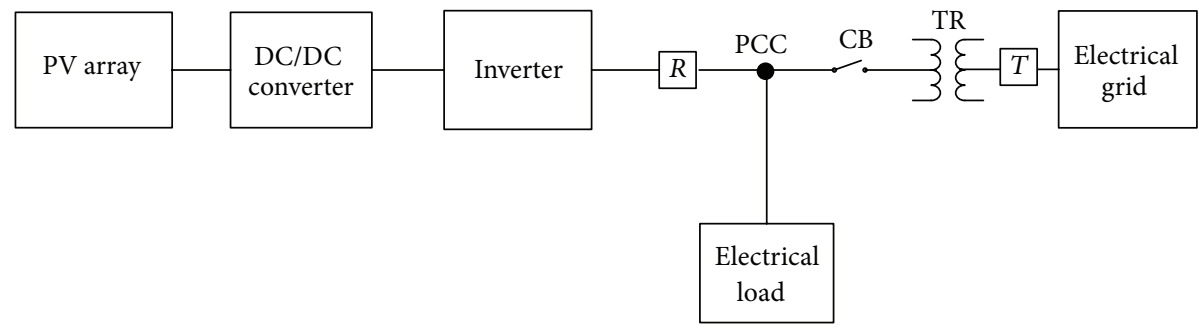

FIGURE 6: The general structure of communication based methods.

when the grid is disconnected from PV system disturbance signal has a significant change compared to the normal running condition. Figure 5 also shows the general structure of active methods in islanding mode of operation.

Communication based methods have the best performance, compared to the passive and active methods; because of these methods all circuit breakers are monitored by the control system. Installing sensors and telecommunication devices to the system makes these methods have high system and operating cost. Therefore, communication based methods are generally used in high powered systems having critical loads so power quality does not change and the system is stable. In addition, these methods are used for the system cost is not important, compared to power quality of the system. The general structure of communication based methods also is shown in Figure 6.

Islanding is an important problem to solve in grid tied PV systems because it could cause serious problems like damaging equipment in PV system and having danger of death for working people. There have been some standards to define some criteria and restrictions for grid tied PV systems in islanding mode of operation. IEEE-1547, IEEE 929, IEC62116, and Japanese standards especially are important for islanding.

Table 1 shows the criteria of some standards about islanding in a grid tied PV system. Islanding detection time, quality factor, allowed frequency, and voltage ranges are indicated in Table 1. The quality factor is selected to be " 1 " in IEEE-1547 and IEC-62116 although quality factor is 2.5 in IEEE-929. In Japan quality factor is selected as zero. Islanding detection time is proposed to be maximum 2 seconds and this time is $500 \mathrm{~ms}$ for passive methods and 1 second for active methods in Japan. This criterion explains that islanding should be detected and PV system should be disconnected from the grid in maximum 2 seconds in any islanding detection method. Frequency and voltage threshold values change compared to the defined electrical criteria of each country so it is important to define threshold values for each country.

Reducing the NDZ, getting a stable power quality, and reducing the system cost in a DG are the main subjects in hybrid methods. Hybrid islanding methods use both active and passive methods behind their algorithms, but today hybrid methods are used only in Japan for real systems [15]. A comparison of current islanding detection methods is shown in Table 2.

Passive methods have a large NDZ and in matching powers of inverter, load, and grid they could have a failure to detect islanding. Active methods have almost no NDZ but they have a power quality problem in the system. Hybrid methods are still suggestion levels. Communication based methods are maybe the best solution for islanding but they have extremely high system and operating cost [16-20].

As a result, from the literature review, nearly all detection methods have no complete solution to the subject. There have been some limitations about these methods and these limitations are given below.

(i) NDZ causes a failure in islanding detection methods.

(ii) There have been power quality and system stability problems in many methods. 
TABLE 1: Current standards for islanding detection.

\begin{tabular}{lcccc}
\hline & IEC 62116 & IEEE 1547 & IEEE 929 & Japan \\
\hline Quality factor & 1 & 1 & 2.5 & 0 \\
\hline Detect. time & $t<2 \mathrm{~s}$ & $t<2 \mathrm{~s}$ & $t<2 \mathrm{~s}$ & Passive: $t<0.5 \mathrm{~s}$ \\
& & $59.3 \mathrm{~Hz}$ & Active: $0.5<t<1 \mathrm{~s}$ \\
\hline Allowed frequency range & $f_{0}-1.5 \mathrm{~Hz}$ & $60.5 \mathrm{~Hz}$ & $59.3 \mathrm{~Hz}$ & Selected value \\
\hline Allowed voltage range & $f_{0}+1.5 \mathrm{~Hz}$ & $V \leq 0.88 V_{0}$ & $V \leq 0.88 V_{0}$ & Selected value \\
& $V \leq 0.85 V_{0}$ & $V \geq 1.10 V_{0}$ & $V \geq 1.10 V_{0}$ & \\
\hline
\end{tabular}

TABLE 2: A comparison of current islanding detection methods.

\begin{tabular}{|c|c|c|c|c|c|}
\hline \multirow[t]{2}{*}{ Features } & \multicolumn{3}{|c|}{ Local methods } & \multicolumn{2}{|c|}{$\begin{array}{l}\text { Remote methods (communication based } \\
\text { methods) }\end{array}$} \\
\hline & Passive & Active & Hybrid & PLL & SCADA \\
\hline Operation principle & $\begin{array}{l}\text { Measuring the PCC } \\
\text { parameters }\end{array}$ & $\begin{array}{l}\text { Adding a disturbance } \\
\text { signal to the grid }\end{array}$ & $\begin{array}{l}\text { A combination of } \\
\text { active and passive } \\
\text { methods }\end{array}$ & $\begin{array}{l}\text { Grid impedance } \\
\text { change in PCC }\end{array}$ & $\begin{array}{l}\text { Using receiver and } \\
\text { transmitter } \\
\text { sensors between } \\
\text { DG and grid } \\
\end{array}$ \\
\hline NDZ & Large & Small & Small & No & No \\
\hline Response time & Short & $\begin{array}{l}\text { Shorter than passive } \\
\text { methods }\end{array}$ & $\begin{array}{l}\text { Longer than active } \\
\text { methods }\end{array}$ & Fast & Faster \\
\hline Detection failure & $\begin{array}{l}\text { Yes, when matching } \\
\text { powers of inverter, } \\
\text { load, and grid }\end{array}$ & $\begin{array}{l}\text { Yes, only in high } \\
\text { quality factor }\end{array}$ & $\begin{array}{l}\text { Smaller than active and } \\
\text { passive methods }\end{array}$ & $\begin{array}{l}\text { No, except a few } \\
\text { specific conditions }\end{array}$ & $\begin{array}{l}\text { No, except a few } \\
\text { specific conditions }\end{array}$ \\
\hline Effect on dist. grid & No & Yes & $\begin{array}{l}\text { Yes, but smaller than } \\
\text { active methods }\end{array}$ & No & No \\
\hline System cost & Minimum cost & Average cost & High cost & Very high cost & $\begin{array}{l}\text { Extremely high } \\
\text { cost }\end{array}$ \\
\hline $\begin{array}{l}\text { Multiple inverter } \\
\text { connection }\end{array}$ & No & Yes & Yes & No & No \\
\hline $\begin{array}{l}\text { Effect on power } \\
\text { quality }\end{array}$ & No & $\begin{array}{l}\text { Decreases the power } \\
\text { quality of the system }\end{array}$ & $\begin{array}{l}\text { Decreases the power } \\
\text { quality of the system, } \\
\text { but with smaller effect } \\
\text { compared to active } \\
\text { methods }\end{array}$ & No & No \\
\hline
\end{tabular}

(iii) There is a false operation when connecting a lot of inverters in a grid tied PV system.

(iv) Installing additional circuits or equipment to the system increases the system and implementation costs.

Most of the proposed methods are still in suggestion level and there have been a few experimental studies about this subject because of the mentioned limitations like nondetection zone (NDZ), power quality, and local load problems. Consequently, PV based microgrid systems need practical and generalized experimental researches that could be widely used in real system applications. Also, there have not been any practical and generalized existing experimental methods that can be widely used in real system applications. Besides, there have been also some innovative and practical studies about this subject recently [21-28].

\section{Proposed Islanding Detection Method}

A lot of methods focus on investigating the point of common coupling (PCC) so all of them are limited to used load and have a NDZ problem. In this study, a new communication based islanding detection method was introduced for grid tied PV systems. A real time controller was developed with Labview and its useful tools for detecting islanding condition. Developed method is a hybrid method which uses the effective ways of communication based and passive methods. In the proposed method, grid, inverter, and load are monitored differently from other methods and loss of mains is checked with controlling the voltages, currents, frequency, and active powers of the whole system. If one of them goes to zero or outside the selected threshold values, digital signals are generated to control circuit breakers. Thanks to this structure, breakers clear the fault only in a few cycles and islanding is independent from the load. 


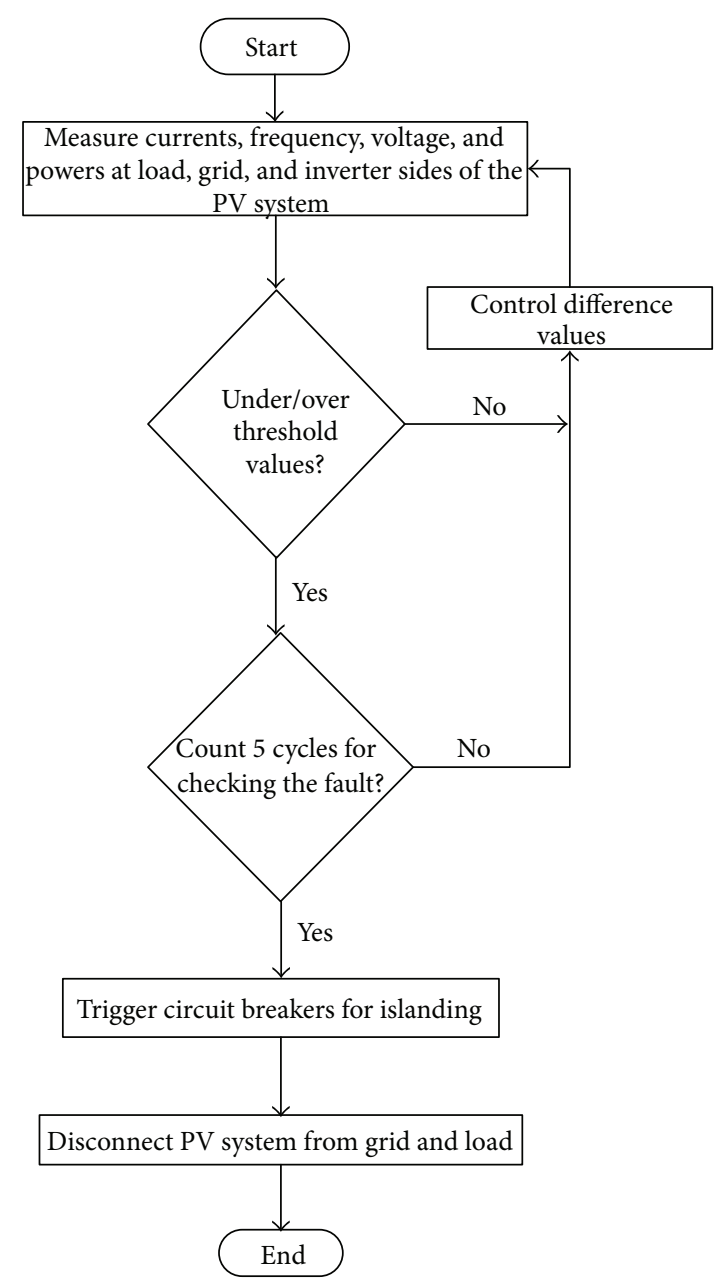

FIgURE 7: Proposed islanding detection algorithm.

Differences in threshold values of grid voltage and grid frequency are detected via proposed islanding detection algorithm. Figure 7 indicates the proposed islanding detection algorithm. In this structure, first of all voltages, current, active power, and frequency values of grid, load, and inverter output are measured. Threshold values continuously are controlled in real time and if threshold values are over/under selected threshold values, control system waits for 5 cycles to check the islanding condition and then a trigger signal is generated for opening circuit breakers where connected grid, load, and inverter output sides.

Grid tied PV system model and islanding detection system model were developed in Simulink before designing the experimental test bench. Figure 8 shows the general structure of proposed PV system connected to the grid and its islanding detection block diagrams. The PV system generates the electrical power and interacts with the grid. If grid voltage or frequency is out of the limitations, circuit breakers were tripped and the PV system disconnected from the grid.

The proposed method has been tested for when the grid voltage is $260 \mathrm{~V}$ ( $\mathrm{rms}$ ) which provides the " $300 \mathrm{~V}<$ $U_{n}<253 \mathrm{~V}^{\prime}$ " condition. When the grid voltage increases up to $253 \mathrm{~V}$, the control system waits for 5 cycles to check the islanding condition, and then a trip signal triggers the circuit breakers. The meaning of $U_{n}$ has been provided. The developed simulation system also has been tested for different load conditions. Figure 9 shows the resistive load $(200 \mathrm{~W})$ condition. Figure 10 shows an inductive load condition (200 W and 400 VAR), and Figure 11 also shows a capacitive load condition (200 W and $400 \mathrm{VAR})$.

\section{Experimental Study and Results}

In this section, grid tied prototype PV system was created in the laboratory and proposed hybrid islanding detection method was described in detail. In general, developed grid connected PV system consists of four main units. These are a PV array, DC/DC converter, inverter, and the electrical load. One kW installed power, PV array shown in Figure 12 was used in developed experimental system. Islanding detection of the PV system was investigated with designing an islanding detection test bench in the laboratory after setting up the grid tied PV system.

In application, a hybrid method was researched for grid tied PV systems to detect islanding so an experimental test system was set up in the laboratory. The general blocks of 


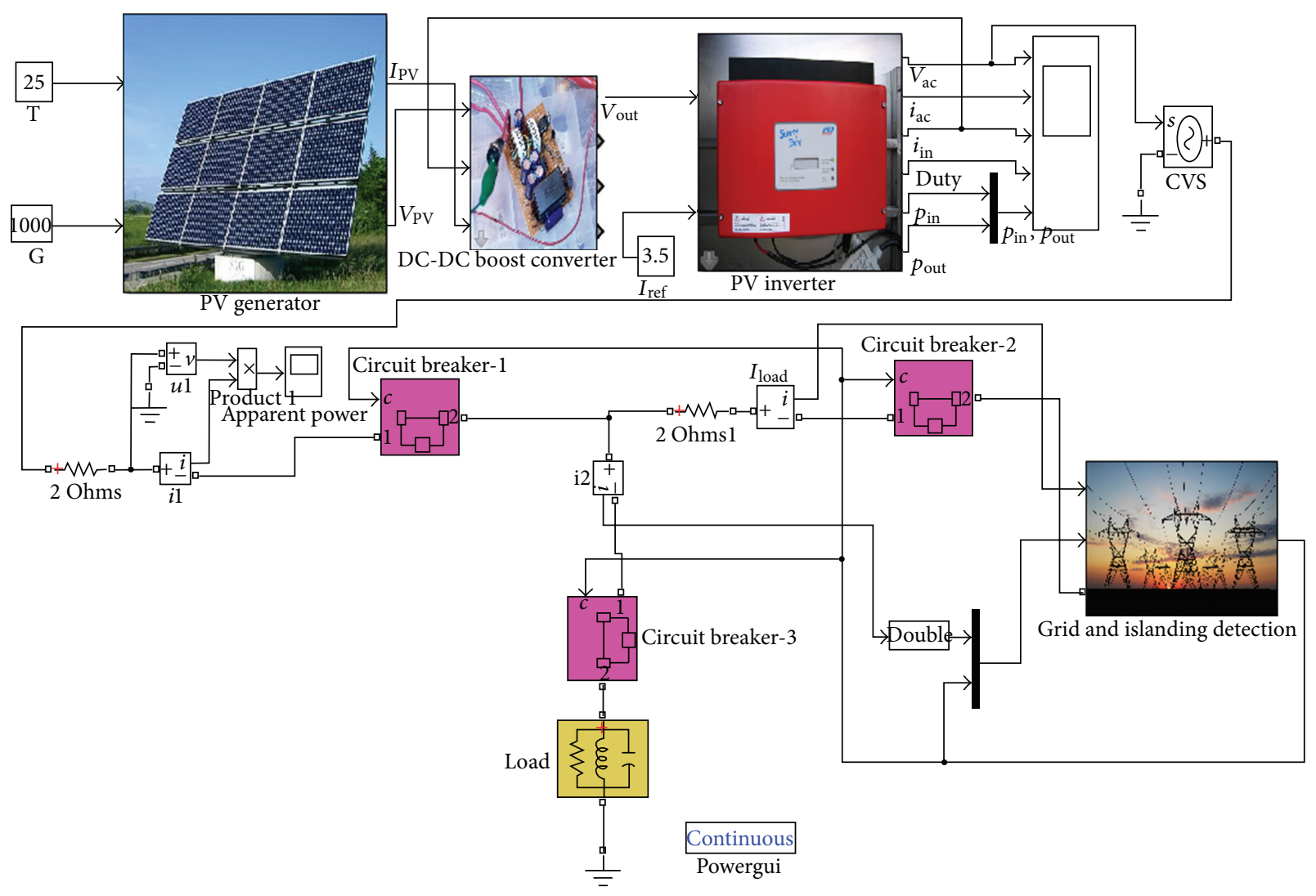

FIGURE 8: Simulation model of the proposed islanding detection method.

developed grid tied PV system is indicated in Figure 13. The output of the PV system was used as a DC supply and a current source inverter was used as a power conditioning unit.

Inverter, load, and grid sides of the PV system were controlled via Labview data acquisition (DAQ) card. Unlike other islanding detection methods, the proposed method monitors all sides of the PV system so it is independent from local load and NDZ which is the most important problem of the islanding detection methods. Electronic measurement cards (EMCs) were used for obtaining the parameters like voltage, current, and frequency and $0-10 \mathrm{~V}$ analog control signals are determined compared to these parameters for controlling the system by giving them to the analog inputs of the Labview DAQ card. The proposed islanding algorithm was developed by using Labview and its useful tools.

Developed test bench for islanding detection shown in Figure 14 consists of EMCs, solid state relays as circuit breakers (CBs), and Labview DAQ card for monitoring and controlling the system. Analog outputs of the EMCs drive the analog inputs of the Labview DAQ card and all of the parameters of the PV system were obtained thanks to this way. Obtained parameters were determined by developing anti-islanding detection software with Labview and its useful tools. Also, all sides of the PV system were monitored in real time thanks to developed software. The proposed method is easily implemented and generally used because of this structure.

The EMCs and circuit breakers can be easily implemented in designing system and minimal hardware is required for implementing the system. The proposed method is also inverter resident so it proposes a robust and reliable solution to the subject.

The EMCs and circuit breakers are also shown in Figure 15. Developed Labview based application software monitors all parameters of the PV system. There are three circuit breakers in the system and voltages, currents, frequency, and active powers of the system are monitored continuously in the PV system. These breakers are switched to controlling the PV system. Developed electronic measurement cards are also shown in Figure 15 as indicated A, B, and C. The loading banks used in the experimental test system are also shown in Figure 16.

Developed Labview based application software monitors all parameters of the PV system and detects islanding when it is occurring. Figure 17 explains the grid tied PV system in normal operating condition and interaction with the grid and the local load. Active power produced by the PV system, requested active power, and transferred power to the grid can be seen in real time and also many parameters like voltage, current, and frequency can be monitored.

There are three circuit breakers in the system and currents and active powers of the system are monitored continuously 


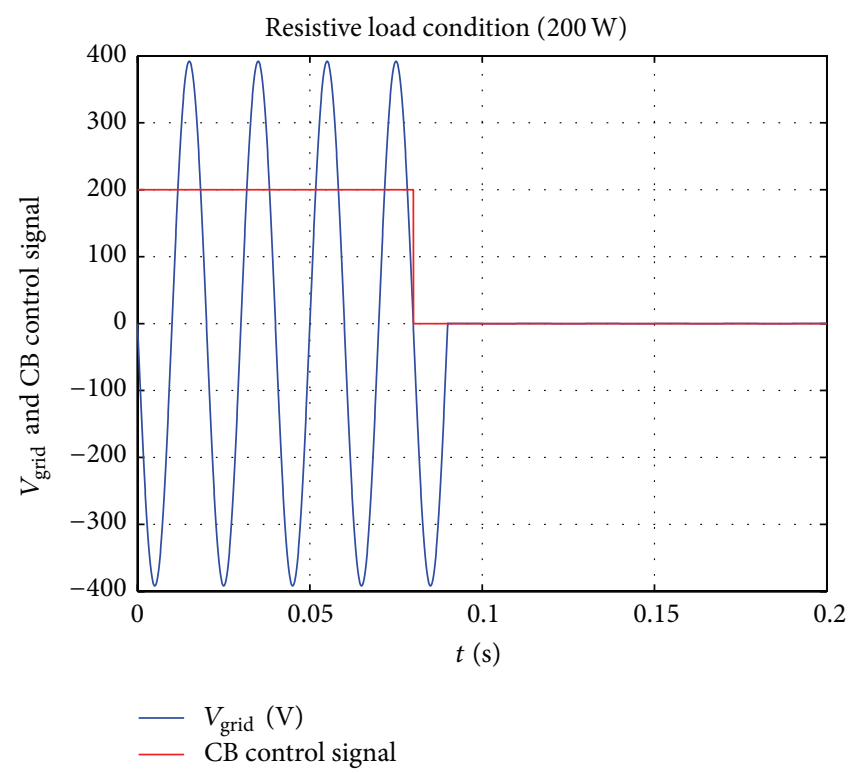

Figure 9: The resistive load condition $(P=200 \mathrm{~W})$.

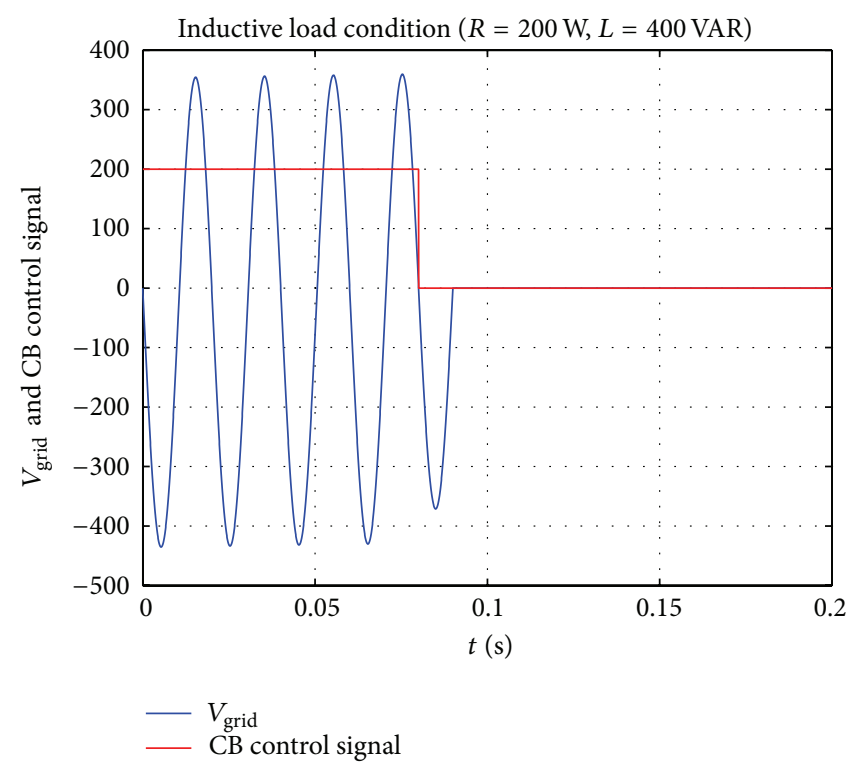

FIGURE 10: The inductive load condition $\left(P=200 \mathrm{~W}\right.$ and $\left.Q_{L}=400 \mathrm{VAR}\right)$.

in the PV system. These circuit breakers are switched when islanding occurred and PV system is isolated from the grid independent from the load. Solid state relays were used in the experimental system for shortening the disconnection time of the system.

Differences in threshold values of grid voltage and grid frequency are detected via proposed islanding detection algorithm. In this structure, first of all voltages, current, active power, and frequency values of grid, load, and inverter output are measured. Threshold values continuously are controlled in real time and if threshold values are over/under selected threshold values, control system waits for 5 cycles to check the islanding condition and then a trigger signal is generated for opening circuit breakers where connected grid, load, and inverter output sides. Selected grid threshold values for this experimental study also could be seen in Table 3 .

Developed islanding detection method continuously evaluates the feedbacks from the PV system and controls all of the system. When islanding occurred, circuit breakers are switched immediately and PV system is disconnected from the grid. Developed software interface in real time for under frequency condition is shown in Figure 18(a). When the grid frequency decreases to $49.7 \mathrm{~Hz}$ as shown in Figure 18(b), control system waits for 5 cycles to check the islanding condition and then a trip signal triggers the circuit breakers. 


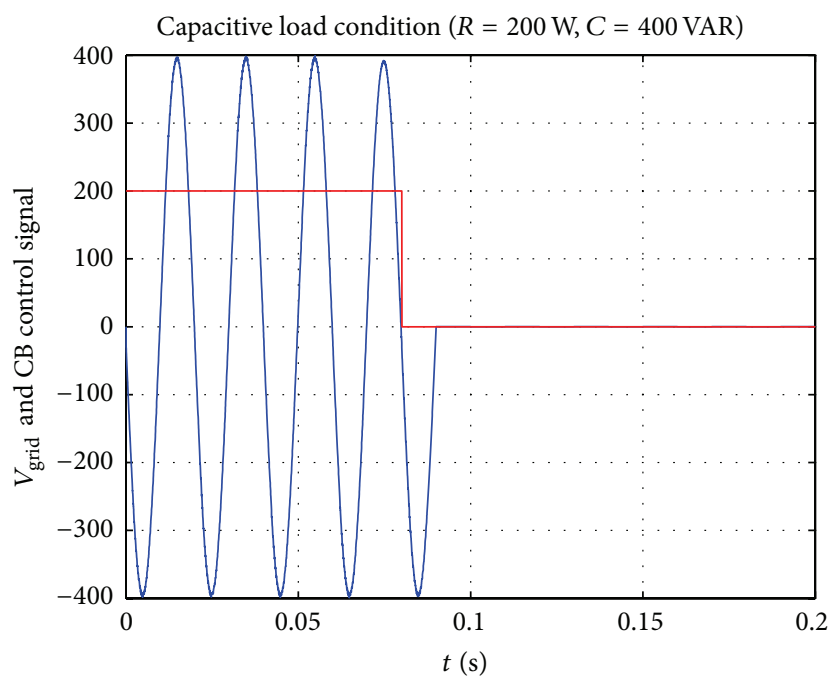

FIgURE 11: The capacitive load condition $\left(200 \mathrm{~W}\right.$ and $\left.Q_{C}=400 \mathrm{VAR}\right)$.
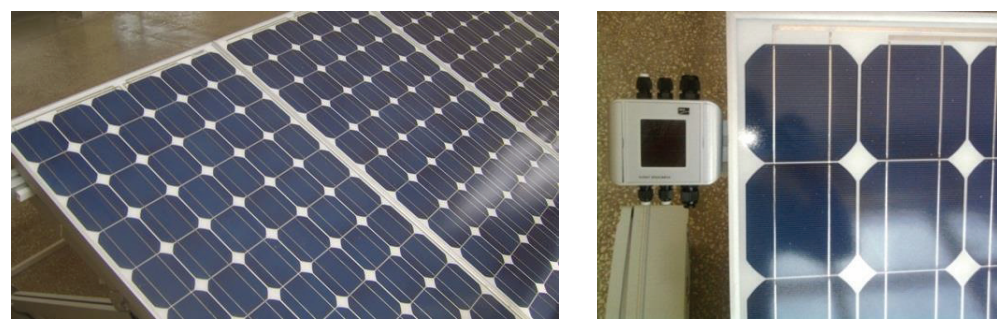

FIGURE 12: Used PV array for grid tied PV system.

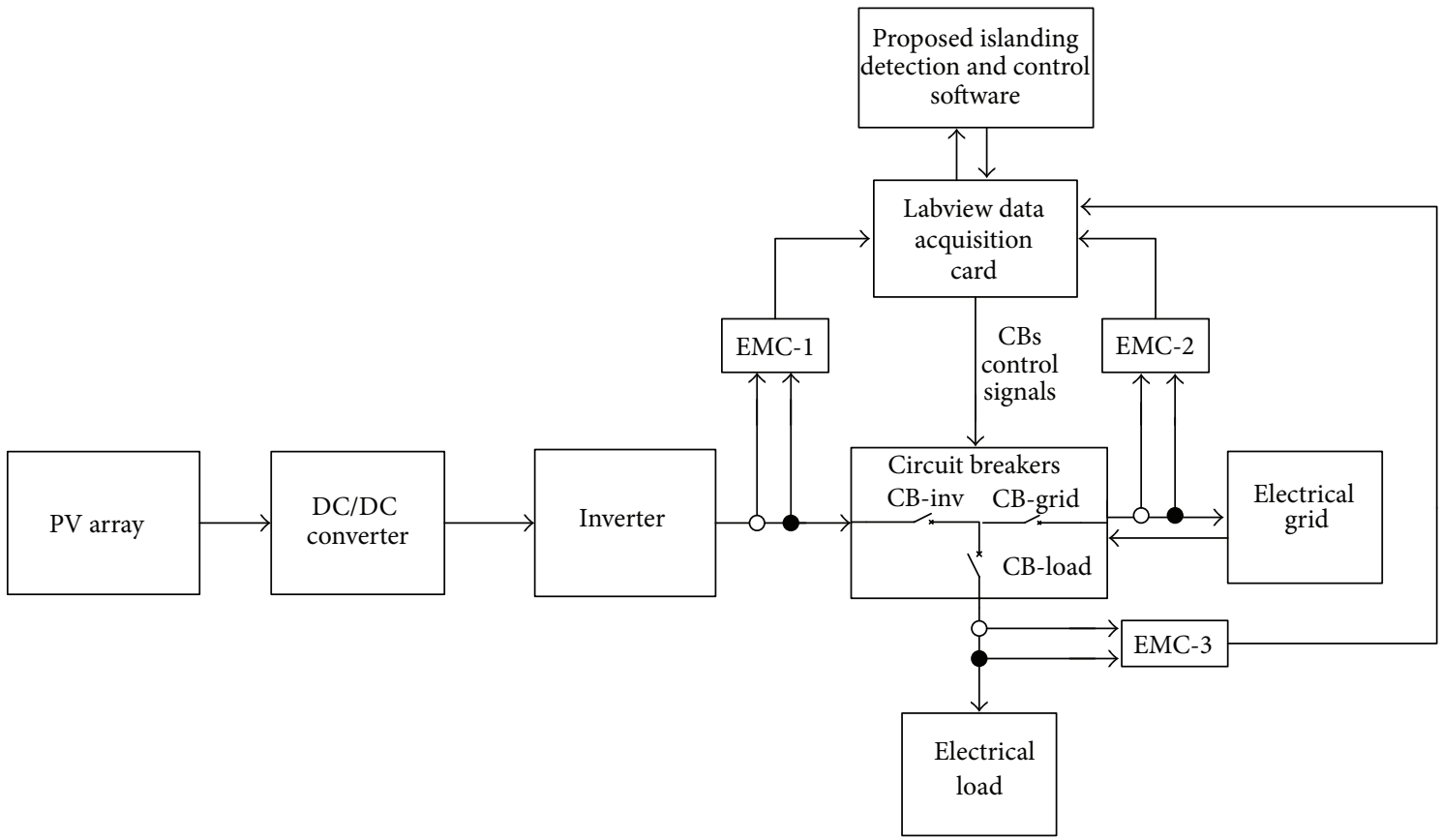

○ Current sensor

- Voltage sensor

FIGURE 13: The general structure of developed grid tied PV system and proposed islanding detection test system. 


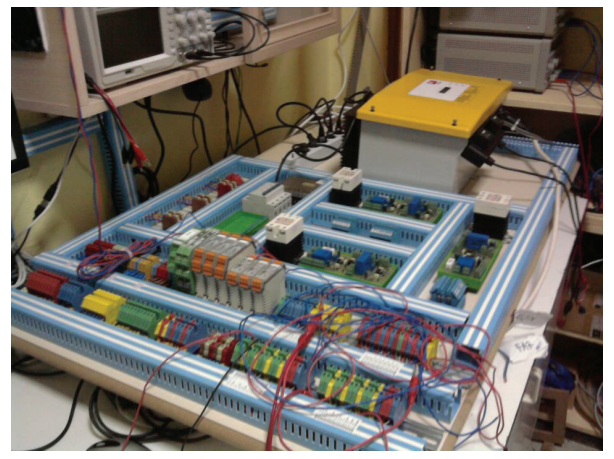

FIGURE 14: The developing islanding test system in laboratory.

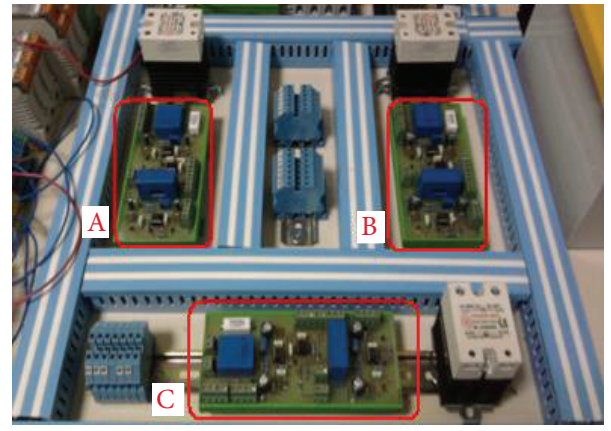

FiguRE 15: Developed electronic measurement cards and circuit breakers.

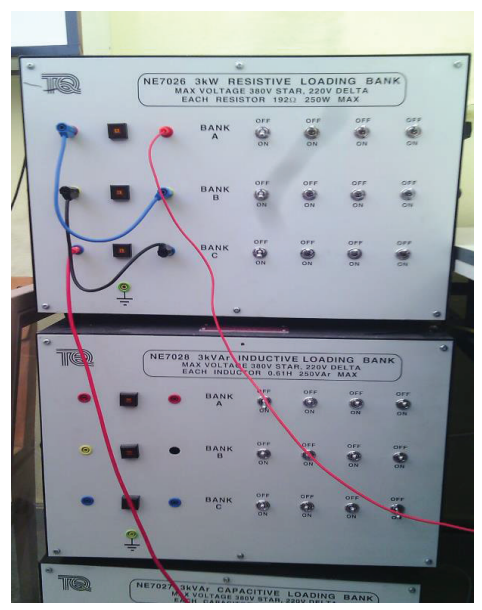

FiguRE 16: The loading banks used in the experimental test system.

When islanding occurred, circuit breakers are switched immediately and PV system is disconnected from the grid. Circuit breaker of the grid (CB_grid) and circuit breaker of the inverter output (CB_inverter) are triggered by generating control signals and these circuit breakers are switched for disconnecting PV system from the grid. This situation is also indicated in Figure 19.

In experimental studies, electrical load specification was selected as $R=300 \Omega, L=0,16 \mathrm{H}$, and $C=2,5 \mathrm{mF}$. These parameters define a resonance condition $(50 \mathrm{~Hz})$ and this is the worst scenario for islanding detection. Besides, active powers of the load and the grid were made equal to approximately $185 \mathrm{~W}$ while generating active power nearly $370 \mathrm{~W}$ from inverter. In this situation, grid current was observed in real time as in Figure 20. After recognizing over frequency condition, the system detects islanding in 1-2 cycles and then waits for 5 cycles for checking the fault. Circuit breakers clear the fault approximately in 2-3 cycles under this load condition. It can be seen that detection time is only 1-2 cycles in proposed method and all detection and fault clearing 

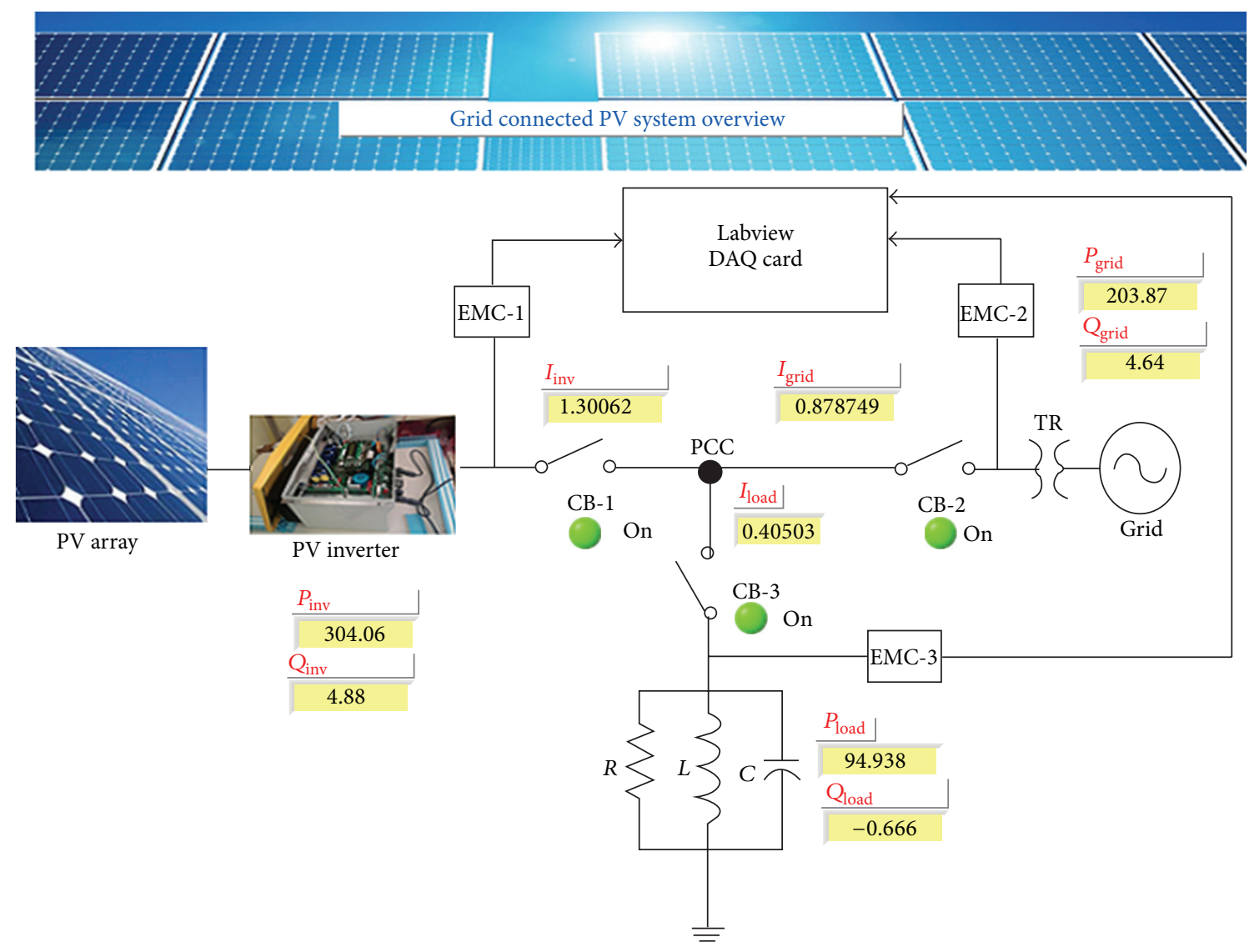

FIGURE 17: Grid tied PV system with developed software interface.

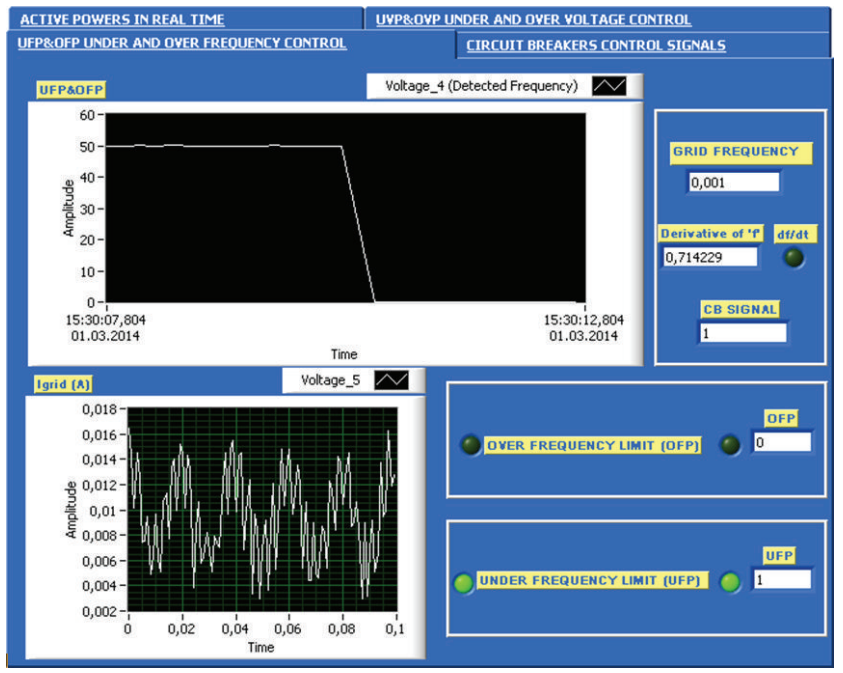

(a)

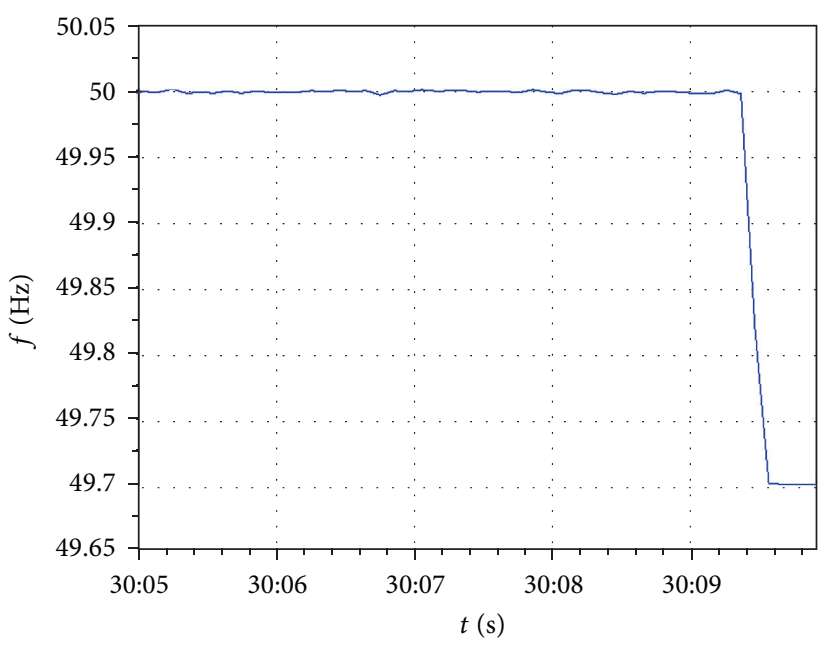

(b)

FIGURE 18: Frequency change of the system in real time (under frequency condition).

time is acceptable compared to IEEE 929-2000. The active power of load for under frequency condition is also shown in Figure 21.

Developed islanding detection method continuously evaluates the feedbacks from the PV system and controls all of the system. When islanding occurred, circuit breakers are switched immediately and PV system is disconnected from the grid. Developed software interface in real time for over frequency condition is shown in Figure 22(a). When the grid frequency increases to $50.3 \mathrm{~Hz}$ as shown in Figure 22(b), 


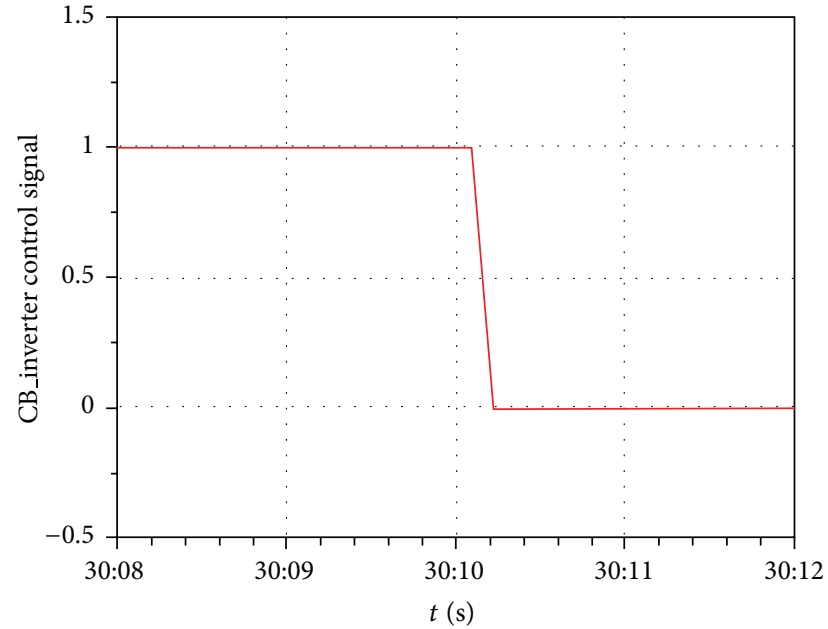

(a)

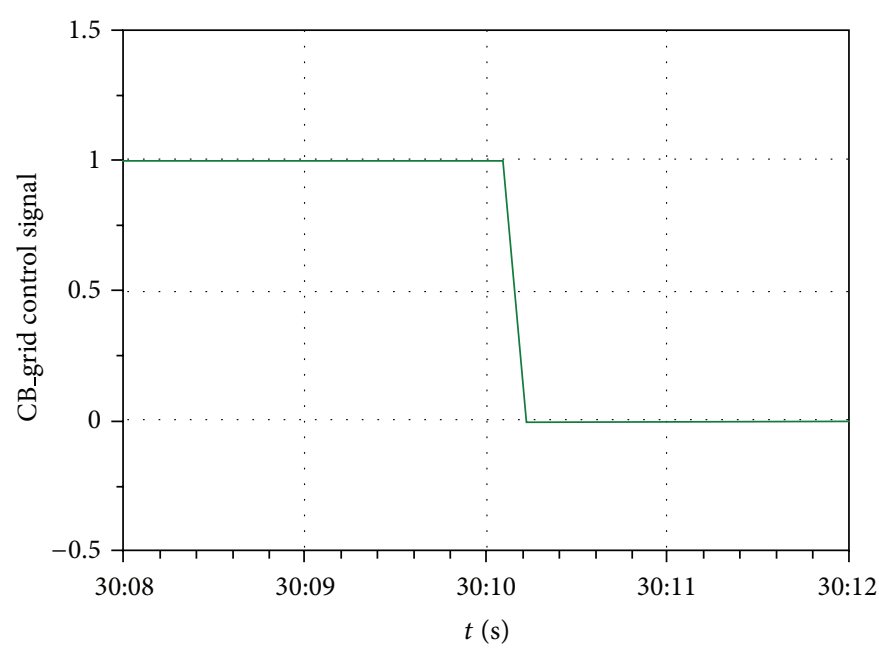

(b)

Figure 19: Control signals of circuit breakers for under frequency condition.

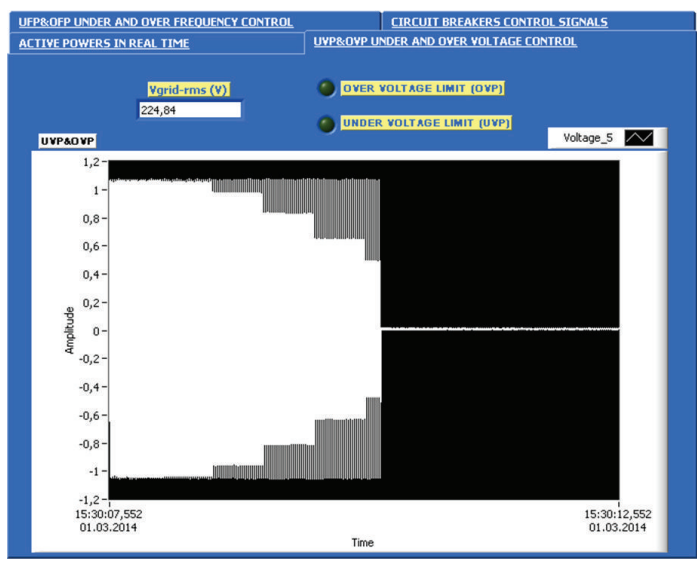

(a)

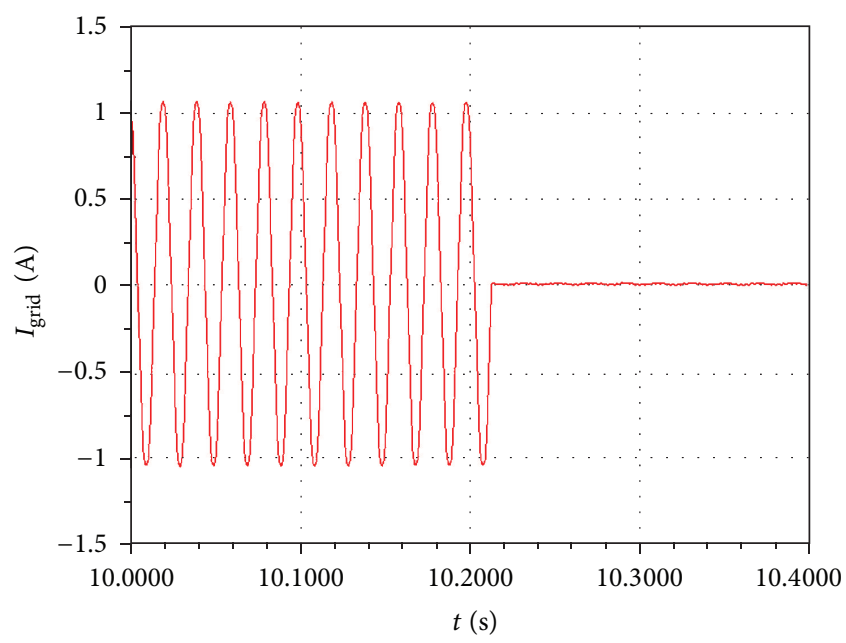

(b)

FIGURE 20: Grid current change for under frequency condition.

TABLE 3: Selected grid threshold values in experimental system.

\begin{tabular}{lcc}
\hline $\begin{array}{l}\text { Selected threshold } \\
\text { values }\end{array}$ & Experimental Study & IEEE 929-2000 \\
\hline Over voltage & $253 \mathrm{~V}(\mathrm{rms})$ & $253 \mathrm{~V}(\mathrm{rms})$ \\
Under voltage & $195 \mathrm{~V}(\mathrm{rms})$ & $195 \mathrm{~V}(\mathrm{rms})$ \\
Nominal voltage & $220 \mathrm{~V}(\mathrm{rms})$ & $220 \mathrm{~V}(\mathrm{rms})$ \\
Over frequency & $50.2 \mathrm{~Hz}$ & $59.3 \mathrm{~Hz}$ \\
Under frequency & $49.8 \mathrm{~Hz}$ & $60.5 \mathrm{~Hz}$ \\
\hline
\end{tabular}

control system waits for 5 cycles to check the islanding condition and then a trip signal triggers the circuit breakers.

In experimental study, electrical load specification was selected as $\mathrm{R}=576 \Omega, \mathrm{L}=0,16 \mathrm{H}$, and $\mathrm{C}=2,5 \mathrm{mF}$. This parameter defines a resonance condition and this is the worst scenario for islanding detection. Besides, active powers of the load and the grid were made equal to approximately $100 \mathrm{~W}$ while generating active power nearly $200 \mathrm{~W}$ from PV inverter. In this situation, grid current was observed in real time as in Figure 23.

Over voltage and under voltage threshold values were also determined in developig islanding detection methods. Developed software interface for over voltage condition is indicated in Figure 24. When the grid voltage is over defined threshold value $(253 \mathrm{~V})$, control system waits for checking the islanding condition and then a trigger signal is generated for circuit breakers and islanding is detected. Figure 25 explains this situation. Grid voltage increases over the threshold value $253 \mathrm{~V}$, circuit breakers are switched off, and PV system is 


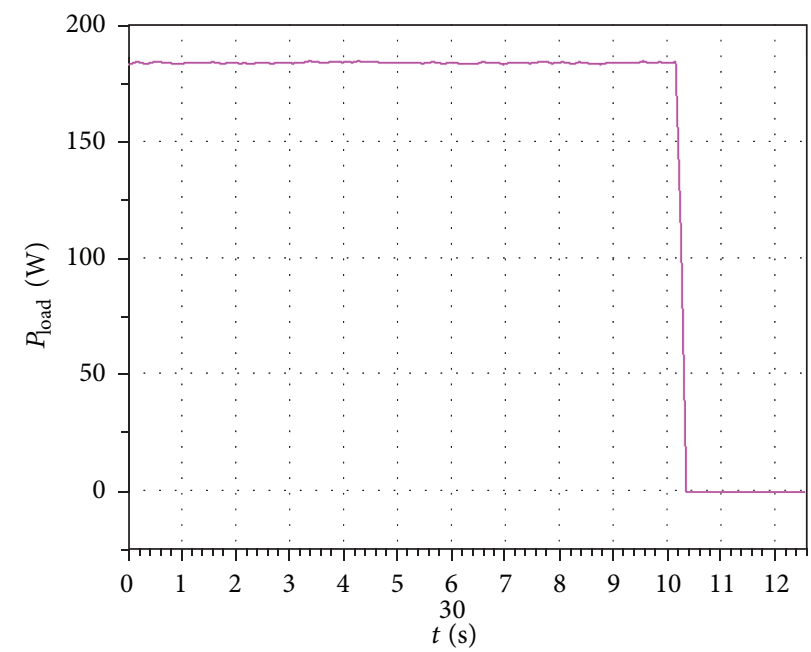

Figure 21: Active power of load for under frequency condition.

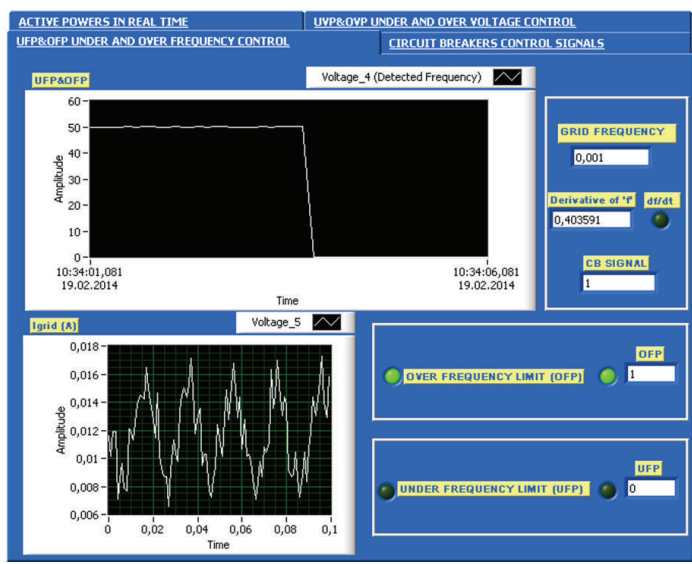

(a)

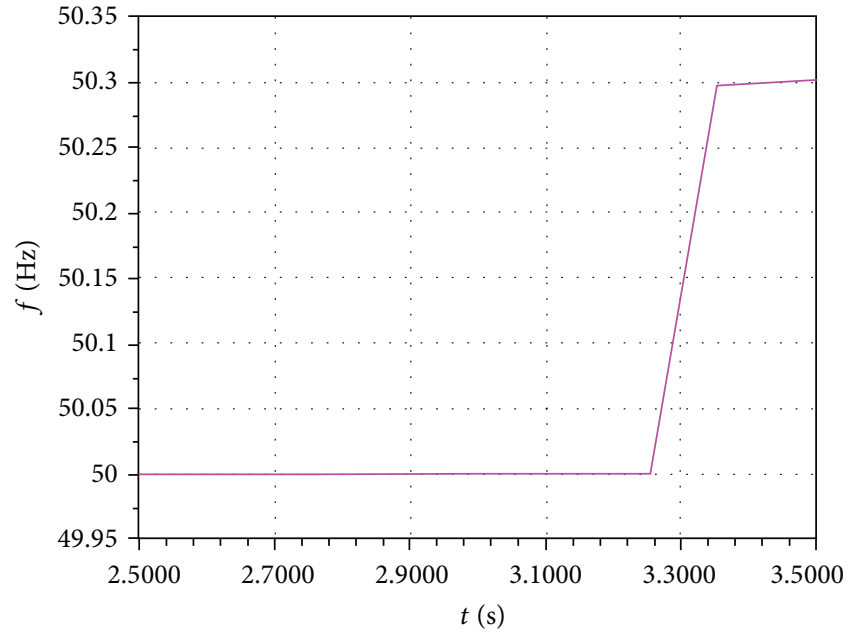

(b)

FIGURE 22: Frequency change of the system in real time (over frequency condition).

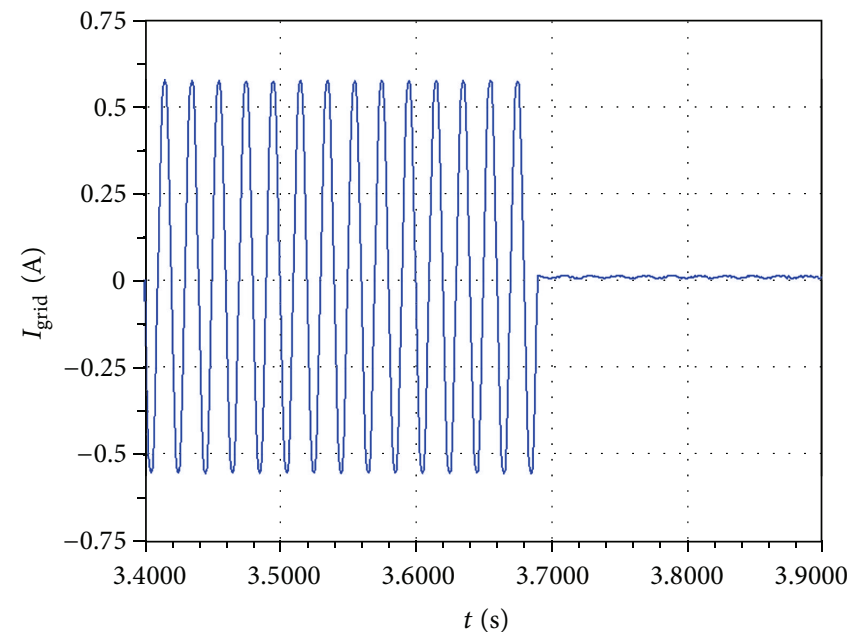

FIgURE 23: Grid current change for over frequency condition. 


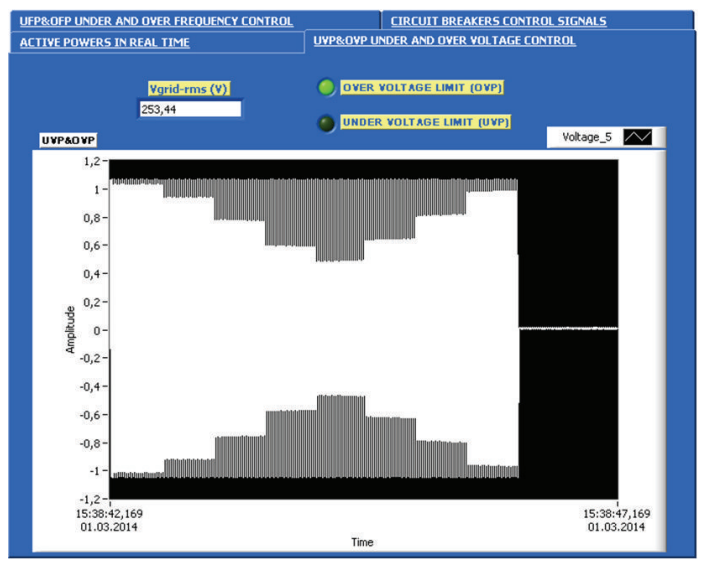

(a)

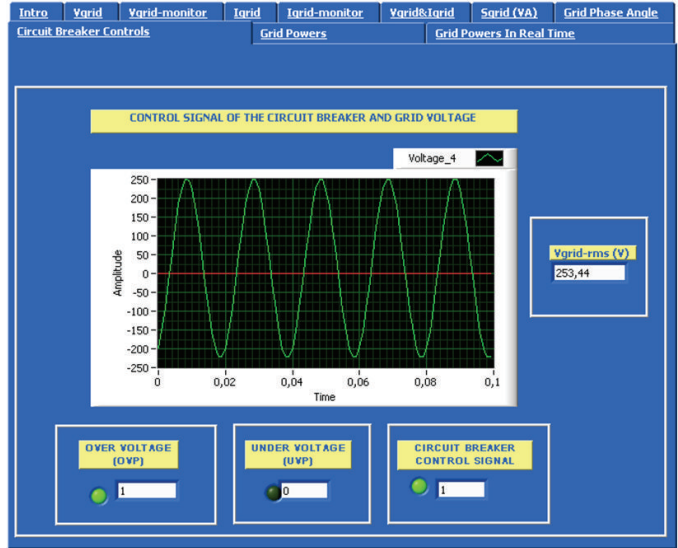

(b)

FIGURE 24: Software interface for over voltage condition.

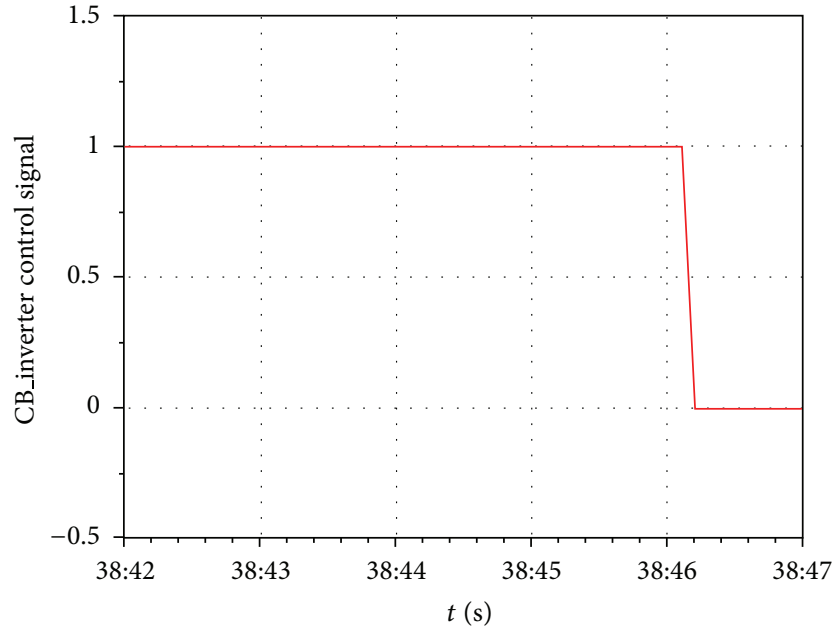

(a)

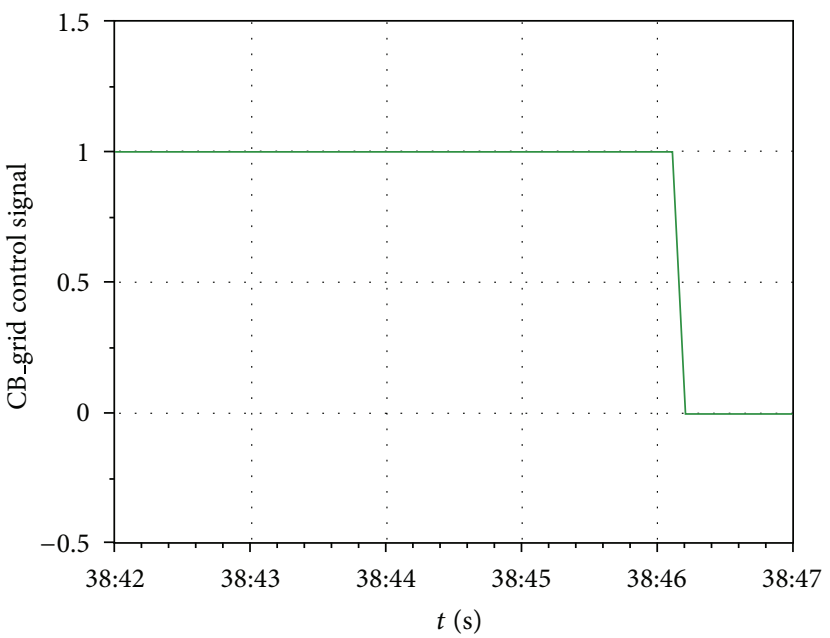

(b)

FIGURE 25: Control signals of circuit breakers for over voltage condition.

disconnected from the grid. Grid voltage for over voltage condition is also shown in Figure 26.

Developed software interface for under voltage condition is indicated in Figure 27. When the grid voltage is under defined threshold value $(195 \mathrm{~V})$, control system waits for checking the islanding condition and then a trigger signal is generated for circuit breakers and islanding is detected. Figures 28 and 29 explain this situation. Grid voltage decreases under the threshold value $195 \mathrm{~V}$, the circuit breaker is switched off, and PV system is disconnected from the grid.

\section{Conclusion}

In this study, a new communication based islanding detection method was developed for grid tied PV systems. Developed method is a hybrid method which uses the effective ways of communication based methods. Islanding detection time is approximately 1-2 cycles even in a resonance condition, and active power compatibility for islanding detection and this condition was indicated in experimental results. The results obtained from the proposed real time islanding detection method show that proposed method is reliable, robust, and independent from load and inverter. Nondetection zone (NDZ) is almost zero and islanding detection time is approximately 1-2 cycles indicated in experimental results, so this time has a significant short response time compared to IEEE 929-2000 standard. In the study, also a simulation model was developed by using Matlab Simulink. The proposed method generates a general solution to the problem and presents a realistic and practical solution compared to other methods. It can be easily adopted to grid tied PV systems and has a reliable and robust solution to the islanding condition. Consequently, it could be implemented easily to grid tied PV systems, and it could be also used in real system applications. 


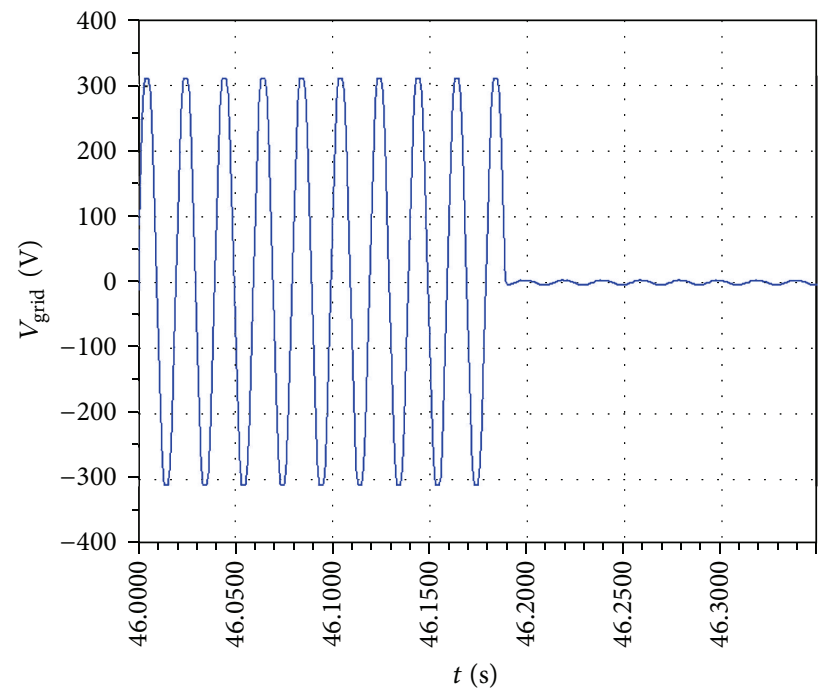

FIGURE 26: Grid voltage for over voltage condition.

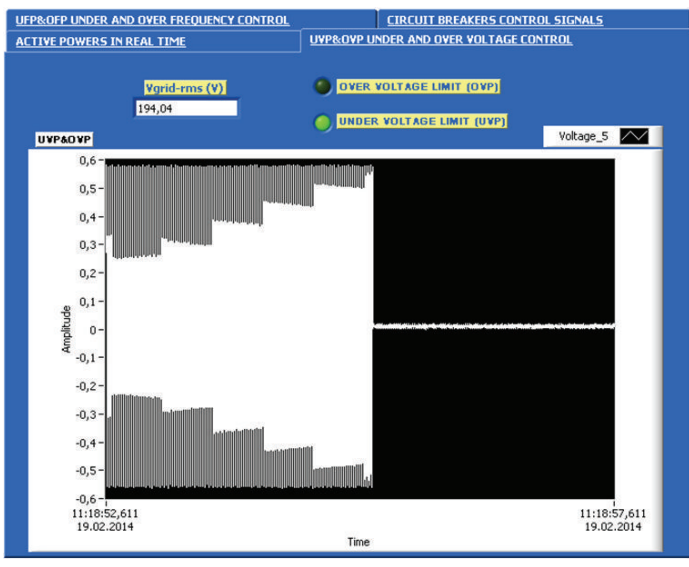

(a)

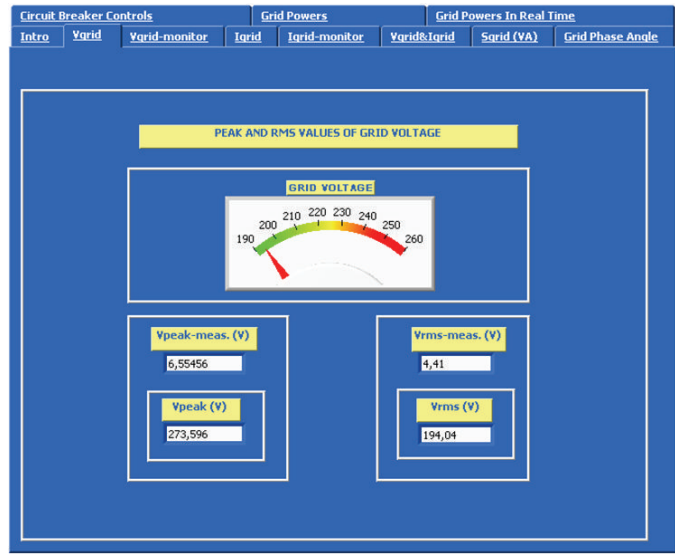

(b)

FIGURE 27: Software interface for under voltage condition.

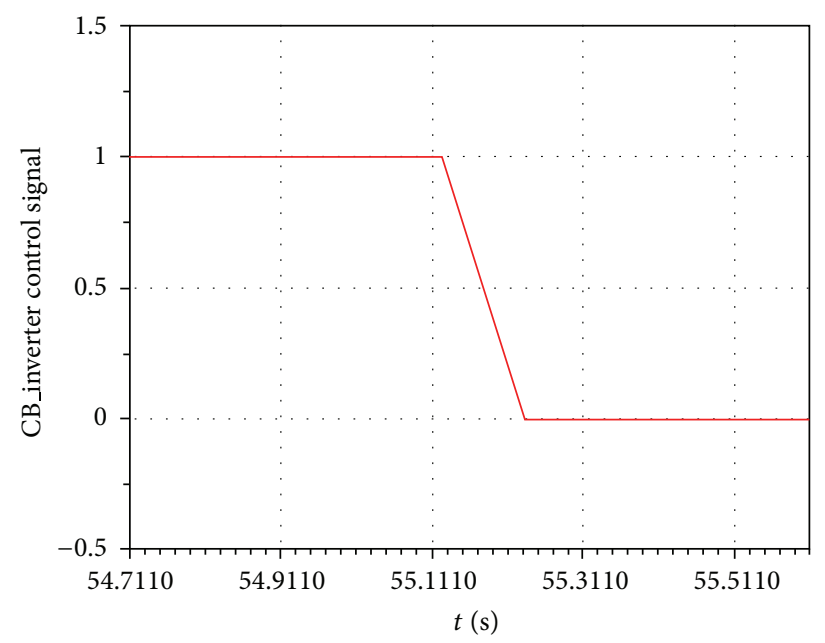

(a)

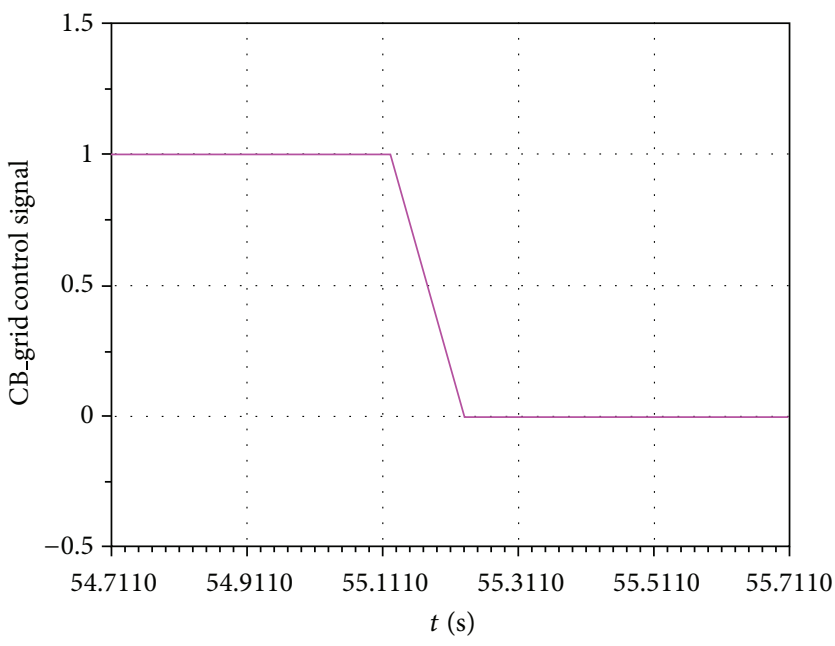

(b)

FIGURE 28: Control signals of circuit breakers for under voltage condition. 


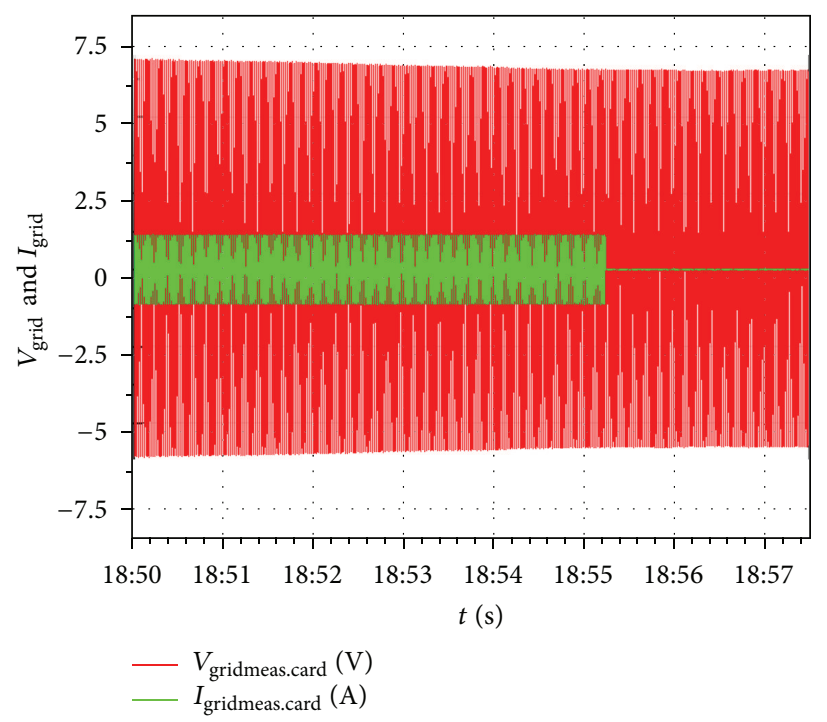

FIGURE 29: Grid current and voltage obtained from EMCs for under voltage condition.

\section{Conflict of Interests}

The authors declare that there is no conflict of interests regarding the publication of this paper.

\section{Acknowledgment}

This study was supported by Firat University Institute of Scientific Research (FUBAP) within the scope of Ph.D. research project MF.11.39.

\section{References}

[1] M. Uzunoglu, O. C. Onar, and M. S. Alam, "Modeling, control and simulation of a PV/FC/UC based hybrid power generation system for stand-alone applications," Renewable Energy, vol. 34, no. 3, pp. 509-520, 2009.

[2] M. Bojić and M. Blagojević, "Photovoltaic electricity production of a grid-connected urban house in Serbia," Energy Policy, vol. 34, no. 17, pp. 2941-2948, 2006.

[3] A. Fernández-Infantes, J. Contreras, and J. L. Bernal-Agustín, "Design of grid connected PV systems considering electrical, economical and environmental aspects: a practical case," Renewable Energy, vol. 31, no. 13, pp. 2042-2062, 2006.

[4] W. Jian, X.-Y. Li, and X.-Y. Qiu, "Power system research on distributed generation penetration," Automation of Electric Power Systems, vol. 29, no. 24, pp. 90-97, 2005.

[5] D. H. W. Li, G. H. W. Cheung, and J. C. Lam, "Analysis of the operational performance and efficiency characteristic for photovoltaic system in Hong Kong," Energy Conversion and Management, vol. 46, no. 7-8, pp. 1107-1118, 2005.

[6] D. Velasco, C. L. Trujillo, G. Garcerá, and E. Figueres, "Review of anti-islanding techniques in distributed generators," Renewable and Sustainable Energy Reviews, vol. 14, no. 6, pp. 1608-1614, 2010.

[7] M. Ciobotaru, R. Teodorescu, P. Rodriguez, A. Timbus, and F. Blaabjerg, "Online grid impedance estimation for single-phase grid-connected systems using PQ variations," in Proceedings of the IEEE 38th Annual Power Electronics Specialists Conference (PESC '07), pp. 2306-2312, Orlando, Fla, USA, June 2007.

[8] M. Liserre, F. Blaabjerg, and R. Teodorescu, "Grid impedance estimation via excitation of LCL-filter resonance," IEEE Transactions on Industry Applications, vol. 43, no. 5, pp. 1401-1407, 2007.

[9] IEEE Application Guide for IEEE Std 1547, IEEE Standard for Interconnecting Distributed Resources with Electric Power Systems, IEEE Std 1547.2-2008, 2009.

[10] A. S. Aljankawey, W. G. Morsi, L. Chang, and C. P. Diduch, "Passive method-based islanding detection of renewable-based distributed generation: the issues," in Proceedings of the Electric Power and Energy Conference (EPEC '10), pp. 25-27, Halifax, Canada, 2010.

[11] C. L. Trujillo, D. Velasco, E. Figueres, and G. Garcerá, "Analysis of active islanding detection methods for gridconnected microinverters for renewable energy processing," Applied Energy, vol. 87, no. 11, pp. 3591-3605, 2010.

[12] V. Menon and M. H. Nehrir, "A hybrid islanding detection technique using voltage unbalance and frequency set point," IEEE Transactions on Power Systems, vol. 22, no. 1, pp. 442-448, 2007.

[13] M. A. Eltawil and Z. Zhao, "Grid-connected photovoltaic power systems: technical and potential problems-a review," Renewable and Sustainable Energy Reviews, vol. 14, no. 1, pp.112129, 2010.

[14] A. Llaria, O. Curea, J. Jiménez, and H. Camblong, "Survey on microgrids: unplanned islanding and related inverter control techniques," Renewable Energy, vol. 36, no. 8, pp. 2052-2061, 2011.

[15] M. Ropp, K. Aaker, J. Haigh, and N. Sabhah, "Using power line carrier communications to prevent islanding," in Proceedings of the 28th IEEE Photovoltaic Specialist Conference, pp. 1675-1678, Anchorage, Alaska, USA, 2000.

[16] S. I. Jang and K. H. Kim, "An islanding detection method for distributed generations using voltage unbalance and total harmonic distortion of current," IEEE Transactions on Power Delivery, vol. 19, no. 2, pp. 745-752, 2004. 
[17] J. Yin, L. Chang, and C. Diduch, "A new adaptive logic phaseshift algorithm for anti-islanding protections in inverter-based DG systems," in Proceedings of the IEEE Power Electronics Specialists Conference, pp. 2482-2486, Recife, Brasil, 2005.

[18] G. Bayrak and M. Cebeci, "Grid connected fuel cell and PV hybrid power generating system design with Matlab Simulink," International Journal of Hydrogen Energy, vol. 39, no. 16, pp. 8803-8812, 2014.

[19] G. Bayrak and M. Cebeci, "3.6 kW installed power PV generator with Matlab Simulink," Erciyes University Journal of the Institute of Science and Technology, vol. 28, no. 2, pp. 198-204, 2012.

[20] N. M. Mahmoodi, B. Hayati, M. Arami, and C. Lan, "Adsorption of textile dyes on Pine Cone from colored wastewater: kinetic, equilibrium and thermodynamic studies," Desalination, vol. 268, no. 1-3, pp. 117-125, 2011.

[21] G. Bayrak and M. Cebeci, "A novel Labview based anti islanding detection method for grid connected PV systems," in Proceedings of the International Conference on Renewable Energy Research and Applications (ICRERA '13) in Special Session: Advances on Solar Energy Technology, pp. 549-554, Madrid, Spain, 2013.

[22] G. Bayrak and M. Cebeci, "Monitoring a grid connected photovoltaic power generation system with Labview," in Proceedings of the International Conference on Renewable Energy Research and Applications (ICRERA '13) in Special Session: Advances on Solar Energy Technology, pp. 562-567, Madrid, Spain, 2013.

[23] G. Bayrak, M. Cebeci, M. T. Gencoglu, M. T. Ozdemir, and Z. Ural, "A novel anti islanding detection method for grid connected fuel cell power generation systems," in Proceedings of the 4to Congreso Iberoamericano Hidrógeno y Fuentes Sustentables de Energía Hyfusen, Córdoba, Argentina, 2013.

[24] M. T. Ozdemir, G. Bayrak, Z. Ural, M. T. Gencoglu, and M. Cebeci, "Implementation of synchronous generator excited by photovoltaic cell/fuel cell for micro hydro power plants," in 4to Congreso Iberoamericano Hidrógeno Y Fuentes Sustentables De Energía Hyfusen, Córdoba, Argentina, 2013.

[25] G. Bayrak and M. Cebeci, "A novel anti islanding detection method for grid connected fuel cell power generation systems," International Journal of Hydrogen Energy, vol. 39, no. 16, pp. 8872-8880, 2014.

[26] M. T. Ozdemir, M. Sonmez, and A. Akbal, "Development of FPGA based power flow monitoring system in a microgrid," International Journal of Hydrogen Energy, vol. 39, no. 16, pp. 8596-8603, 2014

[27] X. Zheng, Q. Li, P. Li, and D. Ding, "Cooperative optimal control strategy for microgrid under grid-connected and Islanded modes," International Journal of Photoenergy, vol. 2014, Article ID 361519, 11 pages, 2014.

[28] Y. Yang and F. Blaabjerg, "Low-voltage ride-through capability of a single-stage single-phase photovoltaic system connected to the low-voltage grid," International Journal of Photoenergy, vol. 2013, Article ID 257487, 9 pages, 2013. 

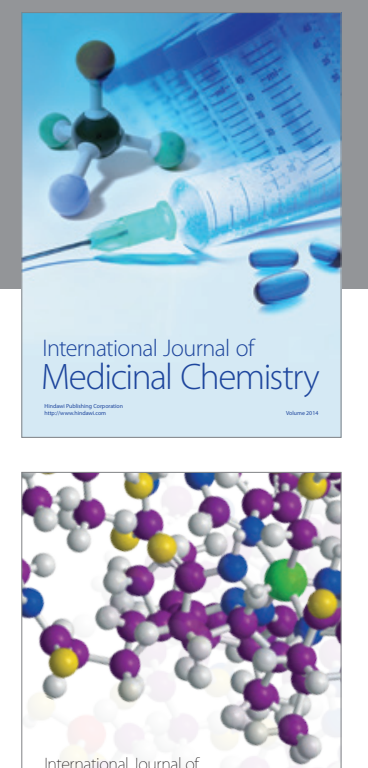

\section{Carbohydrate} Chemistry

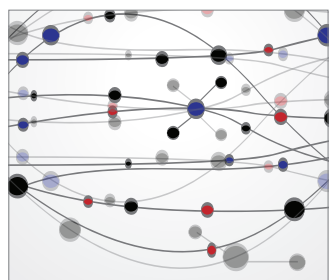

The Scientific World Journal
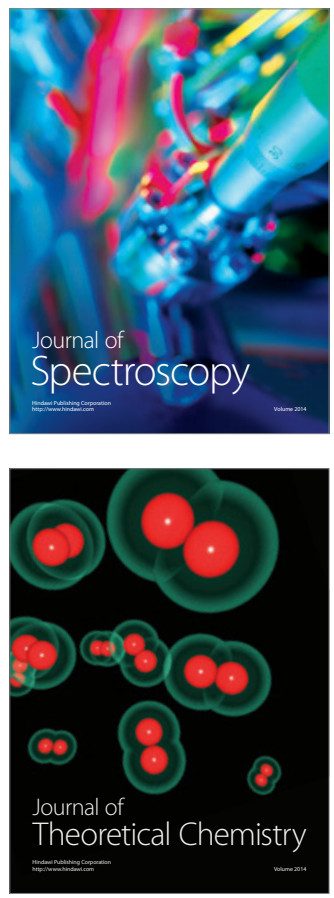
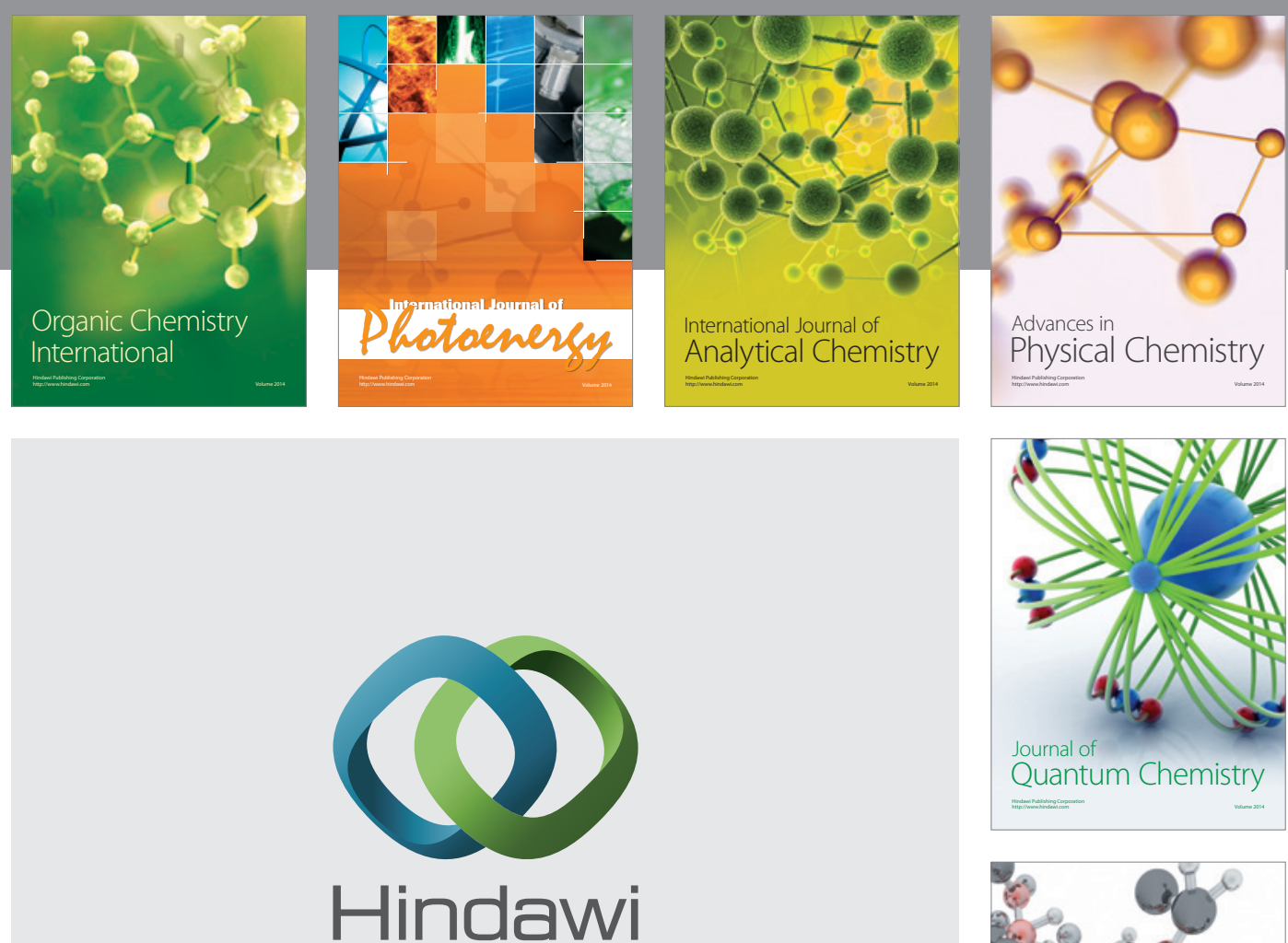

Submit your manuscripts at

http://www.hindawi.com

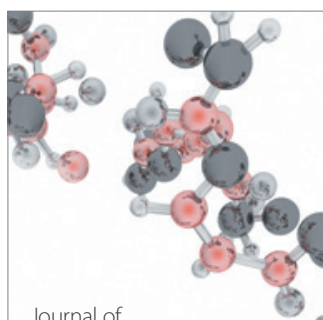

Analytical Methods

in Chemistry

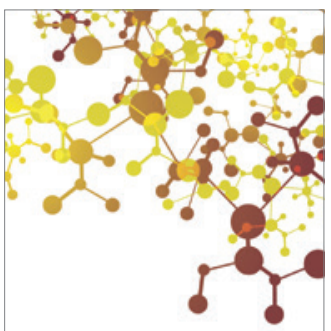

Journal of

Applied Chemistry

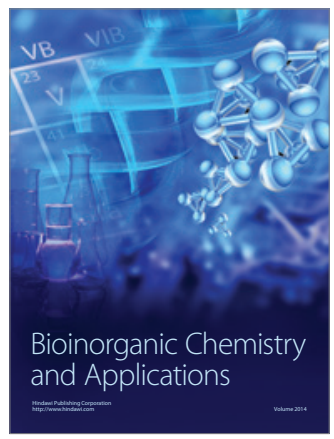

Inorganic Chemistry
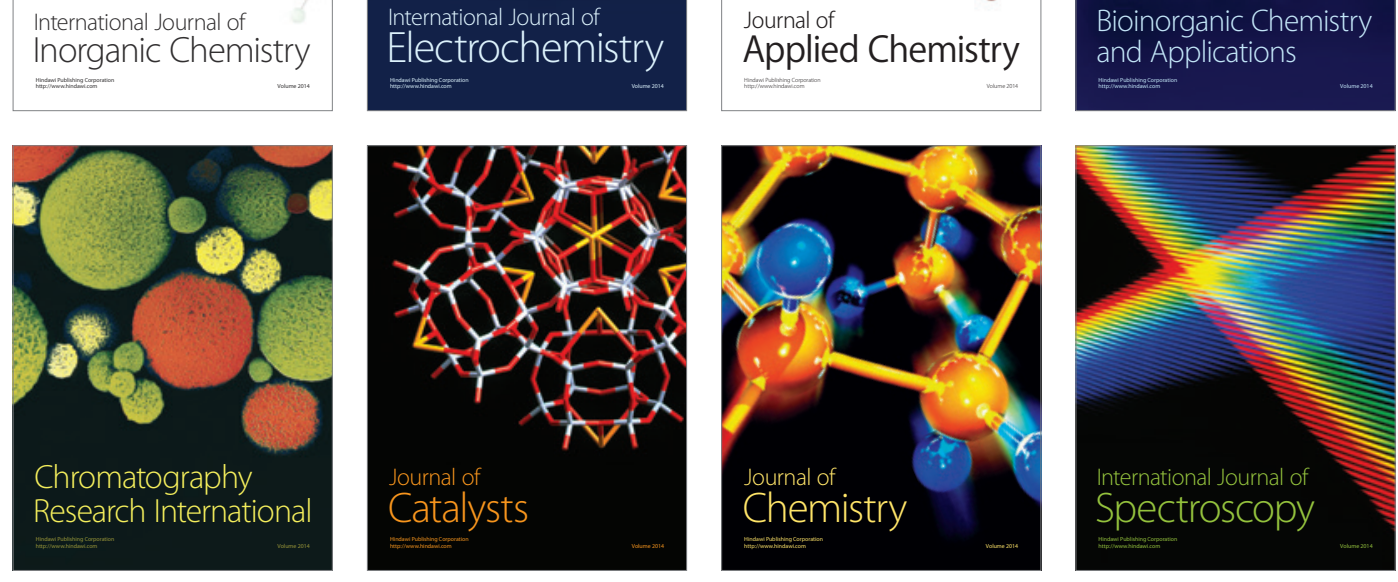